\title{
The Demand for Redistribution: A Test on Hungarian Data*
}

\author{
ISTVÁN GYÖRGY TÓTH** \\ Tárki Social Research Institute, Budapest
}

\begin{abstract}
Rational choice theories of the size of government would predict larger demand for redistribution (and, as a consequence, a higher level of redistribution) in more unequal representative democracies operating under conditions of majority voting. To explain the actual mismatch between the distribution of incomes and preferences, the logic of pure self-interest can be refined by introducing past mobility experience and future mobility expectations. In addition, ideological attitudes and values (for example, about the role of individual responsibility in society) are in this respect also assumed to define general welfare attitudes. This article looks at the explanations of the actual intensity of the demand for redistribution in a transition country that shows high levels of support for various state activities while not showing an extremely high level of inequalities.
\end{abstract}

Keywords: inequality aversion, subjective mobility, demand for redistribution, welfare attitudes

Sociologický časopis/Czech Sociological Review, 2008, Vol. 44, No. 6: 1063-1087

\section{Introduction}

The assumption that demand for redistribution highly correlates with income levels is widely held, often tested, and sometimes questioned. As for the nature and direction of the assumed relationship between the distribution of incomes and the level of redistribution in a given country, disagreements are even more frequent. Rational theories of the size of government, for example, predict higher demand for redistribution in more unequal representative democracies operating under conditions of majority voting. However, the empirical evidence seems to be mixed in this respect: some countries with larger initial inequalities do not necessarily have a higher level of redistribution and countries with a high level of redistribution, may have very different levels of inequalities. ${ }^{1}$ Macro devia-

\footnotetext{
* I would like to thank three anonymous reviewers for their very useful comments. All remaining errors are my own.

** Direct all correspondence to: István György Tóth, director, Tárki Social Research Institute, Budapest, Budaörsi út 45. H-1112, e-mail: toth@tarki.hu

1 Bénabou [1996] finds very little evidence of this relationship, while Milanovic [2000] finds support for the initial inequality-redistribution relationship. For a review of the rel-
} 
tions from micro predictions may be due to motivational, cognitive, and general ideological reasons.

Motivational explanations are generally based on self-interest (often measured by the actual income situation of citizens/survey respondents). However, it may also be that self-interest, shaded by past mobility experience and future mobility expectations on the one hand and by estimations of assumed gains from potential redistribution on the other hand, and along with risk-taking and riskaverse attidues, all play a role. Cognitive factors will result in inaccurate estimates of a person's own relative income position compared to others. Finally, ideological preconceptions, values, and attitudes are also assumed to define general attitudes towards redistribution.

The article is organised as follows. It begins with a rough overview of the theoretical literature on attitudes towards redistribution and then proceeds to define the demand for redistribution and present the data source. In the next section, socio-economic determinants, conditional preferences and subjective mobility are analysed as possible explanatory factors behind the changing levels of demand for redistribution, and this is followed by a presentation of the results of a multivariate analysis. The article closes with a short summary.

\section{Theoretical context}

The demand for redistribution under majority voting systems is often linked to the extent of inequalities in various countries. The Meltzer and Richard paradigm (hereafter MR; Meltzer and Richard [1981]), for example, would predict that greater inequality leads to higher social spending. An increase in inequality is defined by the increased distance between the median and the average incomes, when individuals differ in their productivity and hence also in terms of their incomes. If the median voter is the same as the person with median incomes, on the assumption of self-interest, he or she would certainly prefer bigger redistribution (higher taxes) than a person with an income above the median would. This would imply a higher level of redistribution in countries with greater inequalities. However, as empirical tests have shown (most recently reviewed in Borck [2007]), the evidence is very mixed to say the least.

Below I try to outline two different types of arguments to account for the differences. On the one hand, explanations based on self-interest may be enhanced by taking into account subjective evaluations of past individual mobility and future expectations. On the other hand, incorporating the fact that people have varying overall ideological commitments and value systems may produce a different path of explanations. Broadly, these are the two paths we will be dealing with in

evant literature, see Borck [2007]. For more on levels of inequalities in OECD countries, see OECD [2008] and for more on European countries, see Tóth (ed.) [2008]. 
this article, while explicitly acknowledgeing the fact that there are a number of other theoretical considerations that are not adequately addressed here. ${ }^{2}$

When trying to account for deviations from the MR model, scholars point out that people, when evaluating their own current material circumstances, are a part of their own stories, including the story of the direction of recent changes in their own economic circumstances, their particular knowledge and beliefs, or their expectations for their fortunes in life. Therefore, it is not only current social status and current material circumstances but also the change in social status (whether actual or perceived, in the past or in the future) that may play a role in defining redistributive preferences.

The most straightforward is the case for the past mobility of individuals. Picketty [1995] in an early article, derived the demand for redistribution from the experience of social mobility. Alesina and La Ferrara [2005] stress the importance of actual social mobility (estimated on the basis of long-term panel studies) as a source of deviation from predictions determined from the income position of respondents (voters). Besides past experiences, future expectations can also define redistributive preferences. For example, redistributive desires of less affluent citizens (below-median voters) may be driven not only by their actual level of income but also by their expectations about the likely improvement of their situation (and their chances to ris above the median) in the future. Bénabou and Ok [2001] developed a formal model of the relationship between redistributive claims and the prospect of upward mobility (they call it the POUM model). They argue that low-income (below median) people may reject redistribution if they expect an improvement in their position, while some currently rich people (or at least some of those above the median), if they are facing challenges of income deterioration, may have good reasons to vote for keeping redistribution arrangements in place. Tests of these hypotheses have shown positive results. Ravallion and Lokshin [2000], for example, found in 1996 that a very high proportion of Russians favoured redistribution, including some of the rich.

${ }^{2}$ Corneo and Grüner [2002], for example, have noted the empirical relevance of the assumption that when people reveal their preferences about levels of redistribution, they may also be following non-egoistic motives (the well-being of others may be part of their own utility functions). Corneo and Grüner call this the 'public values effect', while Fong [2001] observes the influence of social preferences (depending on how the agents perceive determinants of poverty and affluence in their societies: do they associate bad luck or lack of effort with poverty). Other arguments in the literature are that there could be specification aspects not adequately addressed in the models. For example, it could easily be that both the concepts of 'taxes' and 'redistribution' are terms that are too broad and cannot be evaluated independently of their distributional consequences. Instead it could be expected that certain kinds of inequalities would induce a demand for certain kinds of expenditures. Moene and Wallerstein [2001], for example, find that increased inequalities lead to increased support for people who are employed, but not necessarily for people who are currently out of the labour market. 
In a more general context, the opinion respondents formulate may also be based on a general evaluation of the opportunities for social mobility that they associate with the system they live in. In this respect, the belief in the fair operations of the economic system is assumed to contribute to a smaller demand for redistribution [Fong 2001; Alesina and La Ferrara 2005]. The factors attributed to getting ahead in society and the rules of social mobility actually perceived as 'fair' also matter. Picketty [1995] and Fong [2001] found that beliefs about what are the determinants of individual success (whether it is effort or luck that leads to higher positions) are significant predictors of the demand for redistribution. Those who see social mobility less in terms of merits and efforts will accept greater inequalities and will demand less redistribution than those who believe that success is just a matter of luck. ${ }^{3}$

On a more general level, a popular and very influential theoretical interpretation ascribes, for example, the more widespread acceptance of large inequalities in America to an overall acceptance of the vision of the 'American dream'. According to this assertion, the belief that the New World is the land of opportunity may have made Americans more tolerant of inequalities than Europeans, who were faced with more social constraints on personal mobility.

Alesina, Di Tella and MacCulloch [2004] found that inequality has a different impact on Europeans (their happiness is reduced by inequalities) and Americans (for whom the relationship is much less significant, if at all). However, this is not without differentiation across various social groups: while in America the happiness of all four segments they analyse (poor-rich and left-right) seem unaffected by inequalities, in Europe the poor and the left show a strong negative aversion to inequality. ${ }^{4}$ In addition, the authors conclude, this transatlantic difference does not originate in the different preferences of Europeans and Americans, but, rather, in the different perceptions of opportunities for mobility in the US and in European welfare states (that is, people's confidence that social mobility is an option for everyone will lead them to press less for much more redistribution). ${ }^{5}$

\footnotetext{
${ }^{3}$ Related to this, a growing portion of the literature underlines ethnic aspects of crossnational differences in social expenditures. Alesina and Glaeser [2006] and Glaeser [2005] find ethnic heterogeneity (and widespread associations of welfare benefits to ethnic groups) to be the reason for the limited of the American welfare state as compared to the extensive European welfare states.

${ }^{4}$ However, Glaeser [2005] underlines that the remarkable stability of American political institutions (at least compared to the European institutions in the 20th century) and the success of leftist indoctrination in Europe compared to the success of rightist indoctrination in the US may have led to more widespread intolerance for inequalities and a stronger demand for the welfare state in Europe.

${ }^{5}$ Osberg and Smeeding [2006] argue that it is not the evaluations of income differences as such but the different attitudes towards the unfortunate at the bottom end of the income scale that make a difference on the two sides of the Atlantic. Americans tend to ignore poverty more than Europeans. Furthermore, Bratsberg et al. [2006] have shed new light
} 
General risk aversion may also play an important role in determining demand for redistribution. Welfare policies in general constitute an insurance against uncertain future contingencies in private life (risk of illness, job loss, decreased working capacity in old age, child-raising costs, etc.). When forming their opinions about redistribution, individuals may follow the reasoning suggested by John Rawls [1971], who argues that rational actors behind 'the veil of ignorance' (that is, uncertain future positions in an unequal world) will choose the minimax strategy to minimise possible welfare risks.

'Comparison incomes' (that is, when individuals subjectively contrast their own income with that of others rather than with past personal experiences or future personal expectations) can also drive redistributive preferences. As people compare typical cases or groups with each other, based on some knowledge of their material positions, the basis for evaluations may be comparisons of their own positions with others or comparisons of other citizens or groups of citizens with each other. Senik [2005] has reviewed a great deal of empirical evidence and found that studies on 'comparison incomes' in the Netherlands, Germany, the UK and the US show negative signs (that is, the larger the gap between a person's own income and that of the reference group, the less satisfied a person will be with his or her income and life prospects). However, she also reports on studies in transition countries like Hungary, Russia, Poland or the Baltic countries, which shows positive correlations with reference incomes: the higher an individual's incomereference income gap was, the higher the person's satisfaction with his or her own income was. Part of the explanation may lie in the fact that these data refer to the relatively early stages of the transition, when the expectations about a fast improvement in living standards were stronger [Senik 2006]. This may also mean that they were (at the time of the surveys) also in the early stages of the 'tunnel effect', a term coined by Albert Hirschman [1973], arguing that the income growth of others may induce optimism in us even if we are still in a stagnant phase. The transformation of optimism into bitter frustration, depending on the length of period spent waiting for better times, may explain the differences between the experiences of transition countries in different phases of development.

Other analysts argue that certain deviations from the MR prediction can be derived from the complex nature of the human motivations involved in these public policy issues [Lübker 2007; Wong 2004] In addition to pecuniary motives, human conduct may also be driven by preferences embedded in the general value systems that people endorse. Egalitarian attitudes lead to criticism of the reward system of market economies and a preference for redistribution to correct these failures. Also, systems with strong egalitarian features may be criticised

on 'American exceptionalism' by examining a great deal of empirical literature on it. They show that Nordic intergenerational mobility patterns are more turbulent than those in UK mobility indices, which in turn show higher mobility rates than those in the US. They argue that, therefore, the belief in greater American mobility may be a popular myth. 
by the actors involved as systems that put too little stress on merit-related rewards. In other words, in certain regimes (like the transition countries experiencing the move from communism to a capitalistic social order) the moral authority of the free market may form the basis for inequality evaluations [Kelley and Zagorski 2004].

Studies on the legitimation of welfare states assumes that people have aesthetic preferences for certain arrangements in the social fabric, that is, they also derive guidance from ideological value systems when forming their opinion on welfare state expenditures. In some studies, the larger demand for redistribution is also attributed to cultural values and to socialisation (especially in the case of the post-transition countries). Alesina and Fuchs-Schündeln [2005] and Suhrcke [2001] both find a significant effect for the East-West dummy variable when regressed on inequality or redistribution preferences. ${ }^{6}$ Gijsberts [2002] also point out that observed differences in inequality aversion between market economies and the former state socialist countries are not due to differences in the social structure, but, rather, to socialisation and values. A large part of the sociological literature argues that social status determines a great deal of the individual contingencies that can serve as a background to stronger or weaker state preferences. Svallfors [1997], for example, shows that, while the level of support is related to welfare regimes, they are of little use in explaining group differences in welfare attitudes. Instead, class divisions and gender explain differing attitudes towards the welfare state across various welfare regimes. However, as social status in itself cannot explain time series changes or cross-country differences (which remain there even after controlling for different socio-economic differences), a continued search for other possible explanations for attitude differences is warranted.

The rest of this article focuses on trying to uncover the determinants of redistributive attitudes by concentrating on two different directions of theoretical propositions set out above. On the one hand, an attempt will be made to extend the 'self-interest' model towards subjective evaluations of past experiences and future expectations. On the other hand, an effort will be made to identify the role of general ideological commitments in shaping redistribution preferences.

\section{Data and methods}

This article tests the determinants of the demand for redistribution on Hungarian data. As far as the 'real' redistribution trends are concerned, Hungary represents the kind of transition, in which the reforms started relatively early (reform efforts date back to the mid-1980s), and partly owing to this for a long time it seemed like a front-runner. At the same time, inequalities, though they increased signifi-

\footnotetext{
${ }^{6}$ However, some have questioned the existence of a 'socialist legacy' in defining commitments to lower levels of inequality, especially in the case of CIS countries [Murthi and Tiongson 2008].
} 
cantly, did not explode as much as in many other transition countries, and around 2005 Hungary ranked in the middle of a European 'league table' of inequalities [Tóth 2005; Tóth 2008]. However, there is a relatively high level of inequality aversion and a relatively low level of legitimation of the newly experienced income distribution [Tóth 2006]. Both of these can reasonably be expected to be behind the increase in demand for redistribution after the systemic change. Successive governments followed a strategy (to some extent similar to the strategies followed in other Central and Eastern European Countries) of extending the scope of social policies to help smooth the process of structural adjustments [Vanhuysee 2006]. Partly as a result of this, the deficit grew throughout the electoral cycle, exhibiting peaks around elections, which points to the political-economy origins of growing macro-economic imbalances [Palócz 2008]; as parties responded to growing demands for redistribution (though they also contributed to boosting expectations). This context renders it especially interesting to explain what drives the consistently high demand for redistribution in Hungary. ${ }^{7}$ However, the aim here is not to explain Hungary's budget deficits. Instead, the objective is to test theoretical assumptions about the relationship between various socioeconomic factors and redistributive attitudes, with Hungary taken as just an example.

The data used in this analysis are drawn from the 2003 wave of the Tárki Household Monitor survey, which covered (as usual in the history of this series) two thousand households. The survey questionnaire contained a detailed block of questions on welfare attitudes, in addition to the traditional income and labour market question blocks. ${ }^{8}$ To measure the demand for redistribution, an index of pro-state attitudes was created, derived from a set of questions on state involvement in various traditional areas. Table 1 shows the index's elementary question items, together with the frequency distributions of the responses to these questions.

The 'predicted variable' (the demand for redistribution index) is derived from answers to the above questions. The index is created as the sum of z-scores on the responses to the role of the state and markets in job creation, free education, health and social expenditures, housing and agricultural subsidies. The resulting index has an expected value of 0 and a variance equal to 1 . This helps define the intensity of the demand for redistribution, as the value of it will depend on the

\footnotetext{
7 The continuous accumulation of public budget deficits inevitably led to a severe austerity package in 2006, more in the character of tax increases than expenditure cuts in 2006 [Palócz 2008]. However, the effects of this are outside the scope of this article, as the data used here were collected right after the honeymoon period with the socialist government that was elected in 2002 and the announcement of large social expenditure increases in the first period of the electoral cycle.

8 Tárki Household Monitor is a cross-section of 2000 Hungarian households. Respondents include all 16+ persons in the household. Data for 18+ respondents are used in this survey. For more on the survey see Szivós and Tóth [2008].
} 
Table 1. The demand for redistribution: agreement with dichotomous trade-off questions on the role of the state and the market (Hungary, in \%)

\begin{tabular}{|c|c|c|c|c|}
\hline \multicolumn{2}{|c|}{ A: Redistributive option } & \multicolumn{2}{|c|}{ B: Market option } & \multirow[t]{2}{*}{ Total } \\
\hline $\begin{array}{l}\text { Unconditional A } \\
\text { (4) }\end{array}$ & $\begin{array}{l}\text { Rather A } \\
(3)\end{array}$ & $\begin{array}{l}\text { Rather B } \\
(2)\end{array}$ & $\begin{array}{l}\text { Unconditional B } \\
(1)\end{array}$ & \\
\hline \multicolumn{2}{|c|}{$\begin{array}{l}\text { It is the duty of the state to provide } \\
\text { jobs for the unemployed }\end{array}$} & \multicolumn{2}{|c|}{$\begin{array}{l}\text { Solving employment problems should } \\
\text { be left to the market }\end{array}$} & \\
\hline 46 & 36 & 13 & 5 & 100 \\
\hline \multicolumn{2}{|c|}{$\begin{array}{l}\text { The state has the duty to provide } \\
\text { higher education for the young, with- } \\
\text { out tuition fees }\end{array}$} & \multicolumn{2}{|c|}{$\begin{array}{l}\text { Education is an investment, and high } \\
\text { quality university services can only be } \\
\text { ensured with tuition fees }\end{array}$} & \\
\hline 50 & 32 & 12 & 6 & 100 \\
\hline \multicolumn{2}{|c|}{$\begin{array}{l}\text { An important task of the state should } \\
\text { be to spend more on health, education } \\
\text { and social expenditures }\end{array}$} & \multicolumn{2}{|c|}{$\begin{array}{l}\text { Reducing taxes should be more impor- } \\
\text { tant, even if less remains for health, } \\
\text { education and social expenditures }\end{array}$} & \\
\hline 56 & 30 & 9 & 5 & 100 \\
\hline \multicolumn{2}{|c|}{$\begin{array}{l}\text { The housing problems faced by young } \\
\text { people can only be solved with state- } \\
\text { supported construction }\end{array}$} & \multicolumn{2}{|c|}{$\begin{array}{l}\text { The young should solve their own } \\
\text { housing problems, the state should } \\
\text { only become involed through favour- } \\
\text { able mortgages and tax breaks }\end{array}$} & \\
\hline 21 & 20 & 29 & 30 & 100 \\
\hline \multicolumn{2}{|c|}{$\begin{array}{l}\text { Agricultural production should be } \\
\text { supported by the state: without it pro- } \\
\text { ducers would have difficulty surviving }\end{array}$} & \multicolumn{2}{|c|}{$\begin{array}{l}\text { Agricultural products are just like } \\
\text { products in other sectors: agricultural } \\
\text { producers should also have to survive } \\
\text { under market terms }\end{array}$} & \\
\hline 38 & 37 & 17 & 8 & 100 \\
\hline
\end{tabular}

Source: Tárki Household Monitor survey, 2003.

relative position of the individual in the joint distribution of various pro-state variables. The further away an individual is from the centre of the distribution, the higher the (positive or negative) value of the index. For OLS regressions, this sum is predicted. In the bivariate analysis the actual average values by categories are shown. ${ }^{9}$

\footnotetext{
${ }_{9}$ An alternative way of computing the index would have been to begin with principal components extractions. However, as the resulting two components (the items for tuition fees and housing seemed to behave differently from the rest) was fairly balanced and the omission of any items would have resulted in two big information losses, I decided to keep the simple summing up of the values of relative positions (z-scores). However, the Corn-
} 
When trying to find correlates, our assumption is that the demand for redistribution will depend on 1) the economic self-interest of the respondents as measured by objective material variables, 2) subjective evaluations of past mobility experiences and future mobility prospects, 3) the degree of risk aversion of the respondents, 4) the general attitude of the respondents about the role of individuals in securing safe economic positions for themselves and for their families, and 5) the respondents' evaluation of the level of tolerable inequalities. When controlling for the major socio-economic background variables, like gender, age, education, and place of residence, it is hypothesised that these factors exert an influence.

Objective material position (direct economic self-interest) is proxied by two variables. A person's (objective) income position is measured by personal equivalent incomes (net disposable household incomes adjusted by family size ${ }^{10}$ ). It could be expected that lower incomes would correspond to higher redistributive claims. Labour market status is represented by a variable used as a proxy for dependence on existing redistributive arrangements: pensioners and inactives rely to a great extent on pensions or other types of benefits from the state.

Variables on subjective mobility (experiences and expectations) include experienced (subjective) income mobility, with the expectation that downward mobility will result in higher redistributive claims, while upward subjective mobility will be associated with a lower demand for redistribution. This is measured by responses to a question in which people evaluated the current material status of their family and their status a decade earlier on a ten-point social scale. Mobility perceptions are calculated as the differences between these values. Expectations about (subjective) social mobility are expected to have a negative relationship with demand for redistribution. The higher the expected mobility of the person is, the less likely it is that the person will be in favour of redistribution, should other things remain equal. ${ }^{11}$

Among personal attitudes about individual responsibility, two different aspects are distinguished. The first is the general opinion on the role of individual efforts and social responsibilities in shaping one's fortune. This was measured with a self-ranking on a four-value scale measuring commitment to full responsibility for someone's own fate versus the claim that the state should take more

bach alpha is not very high (somewhat less than .43). Still, as this measure is intended to reflect a general attitude to greater or less state involvement, we have to list a broad range of potential state measures in the index (just like the situations voters face in actual elections).

${ }_{10}$ The equivalence elasticity is $\mathrm{e}=0.73$, a value that fits well with the implicit elasticities used in the Hungarian social policy system. It is more restrictive than the assumption of per capita incomes, but allows less economies of scale than the OECD I or OECD II scales [Tóth 2005].

${ }_{11}$ Respondents were asked to assess their satisfaction with their income prospects in the coming year. 
responsibility in caring for its citizens. The expectations are obvious: those committing themselves to a more individualistic view of personal responsibilities will reveal less intensive preferences for redistribution. The second aspect is risk aversion as a general attitude, measured by respondents' choices between the option of secure employment with low gains and the option of high gains but risky employment in a hypothetical situation..$^{12}$ It is expected that risk-averse individuals would show a higher demand for redistribution.

With regard to tolerance of inequality, the evaluation of the actual level of inequalities is expected to have an impact in the demand for redistribution index. It is expected that it has a separate role in explaining the variance of the predicted variable in that the 'stronger' the agreement with the statement about actual inequalities in the country being 'too high', the higher the demand for redistribution will be.

Personal characteristics like 'age' (six categories of ten-year age brackets for the age of respondents), 'education' (differentiating between respondents with less than primary education, vocational education, secondary education, or complete higher education, with the latter group also including students currently attending higher education), 'gender' and 'place of residence' categories (three categories, differentiating between the capital, cities and rural areas).

The next two sections present the bivariate results and some interactions and the multivariate parameter estimates for the effects of predictors on redistributive preferences.

\section{The socio-economic correlates of redistributive claims}

We start the bivariate observation of the data by looking at the basic socio-economic background variables. The general expectation is that socio-economic status (represented by variables like incomes, labour market position, and demographic characteristics, most importantly age) and educational attainment play a primary role in defining who becomes a stronger or weaker supporter of state redistribution.

This assumption is partly supported by the available data. Education seems to be negatively correlated with the redistributive attitude index (Table 2). The value of the index is lower for people with more education and higher for people with less education. The relationship seems to be linear and quite strong. The same applies to incomes, which seem unequivocally negatively correlated with the value of the index. This is very much what we would expect and this is very

\footnotetext{
12 The wording of the question was: Which option would you choose if someone made you two job offers: one job with a continuous, secure flow of relatively lower income, or another job with considerable insecurity, promises of large gains, but a viable threat of big losses, too.
} 
Table 2. The average value of the redistribution attitude index in various socio-economic groups, Hungary, 2003

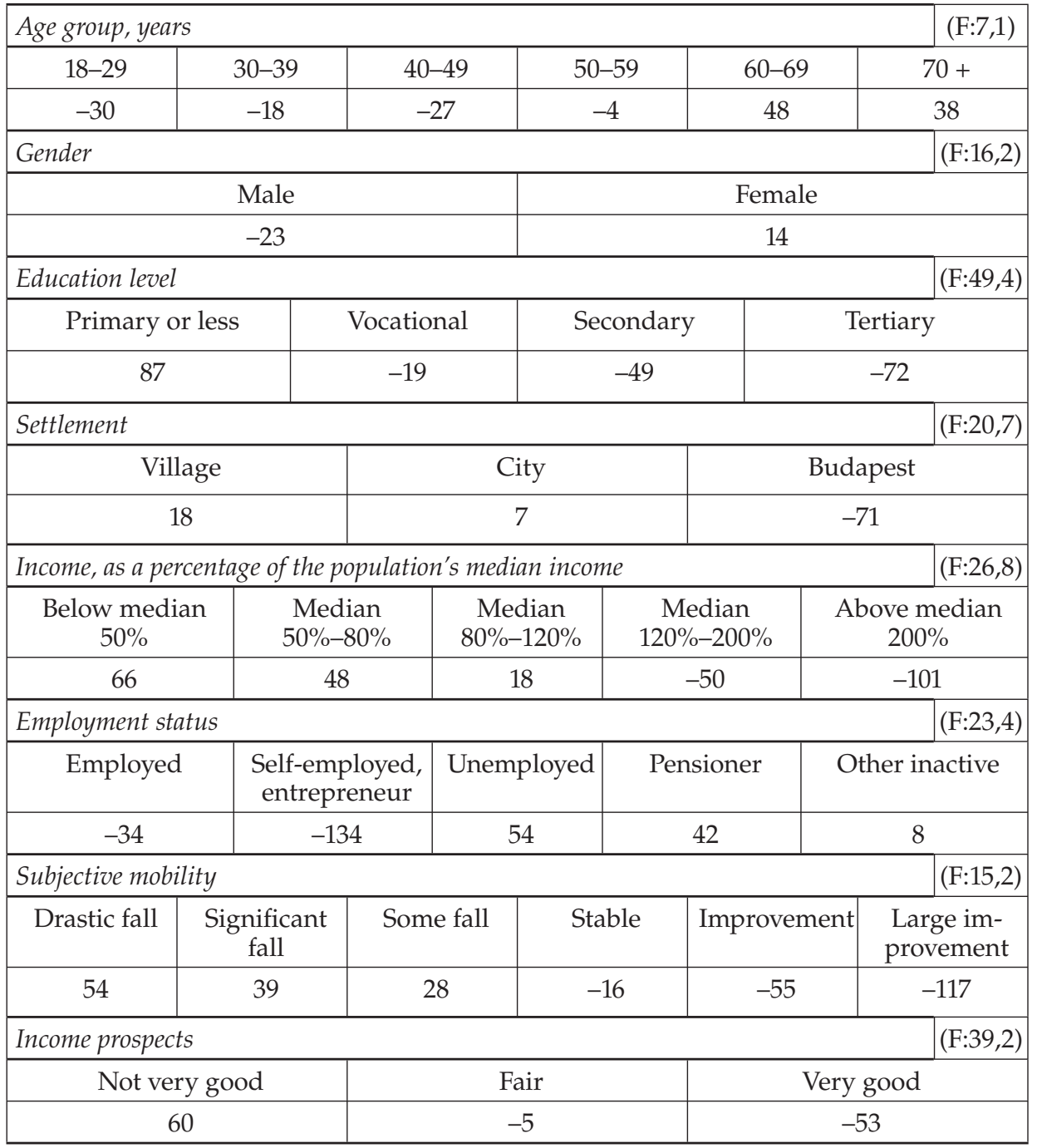

*F statistics in brackets

much what is assumed by public choice models. However, the pattern shown in Table 2 is clearly reminiscent of the glass-half-empty glass-half-full conundrum. The redistributive index by design shows the 'intensity' of state/market preferences of various sub-groups of society. Therefore, while the averages seem to 
correspond to the expected direction of the relationship, this does not mean that, for instance, no high-income persons would vote for redistribution, and it can be supposed that there are also poor who reject redistribution.

As far as generational differences are concerned, the age of respondents does not seem to show any linear connection to redistributive attitudes. Younger respondents expressed a lower level of redistributive preferences than older generations (with the dividing line somewhere around the effective retirement age in Hungary, i.e. 55-60 years of age). However, within these two broad age groups, it is possible to suspect that the differing extent of labour market participation of the different age cohorts has an effect. Entrepreneurs and the self-employed tend to be less supportive and pensioners and the economically inactive more supportive of state redistribution. The economically inactive at the lower end of the age scale (students) may account for the non-linearities in the age distribution of redistributive preferences.

As for gender differences, men tend to favour less redistribution than women. In terms of locality, people living in Budapest tend to favour redistribution less than villagers do. However, composition effects especially should be controlled for.

It is important to note here that the scale being used to measure redistribution was deliberately designed to cover a broader range of activities well beyond vertical redistribution, which is conventionally defined as a target area for welfare attitudes. The relatively higher rate of refusal higher rate of rejection of these measures not only means a rejection of social expenditures but is also the expression of some form of reservations towards the economic involvement of the state.

From a glance at the values redistributive attitude index, grouped by categories of experienced and expected social mobility, a direct negative relationship becomes apparent. Respondents reporting downward shifts in their material circumstances show significantly stronger redistributive preferences than those who evaluate their life course changes as more fortunate (see Table 2, bottom rows).

However, it may well be that there are certain interactions between income levels and experiences or expectations about personal economic prospects that determine the intensity of state preferences. These types of interactions are illustrated in Figure 1.

Past mobility experience seems to correlate negatively with redistributive attitudes at each income level. This is represented by the fact that those who feel that their position has worsened considerably show stronger levels of redistributive preferences at each income level (including the highest). In turn this also means that even people who otherwise belong to the lower-income categories (with less than $80 \%$ of the median income) show less positive attitudes towards state redistribution if they report upward mobility in their immediate past (in contrast with people who belong to the same income category but have not expe- 
Figure 1. Interactions between income level on the one hand and subjective mobility and income expectations on the other in shaping redistributive preferences

Panel A: Values of the redistributive index by subjective income mobility in the past year

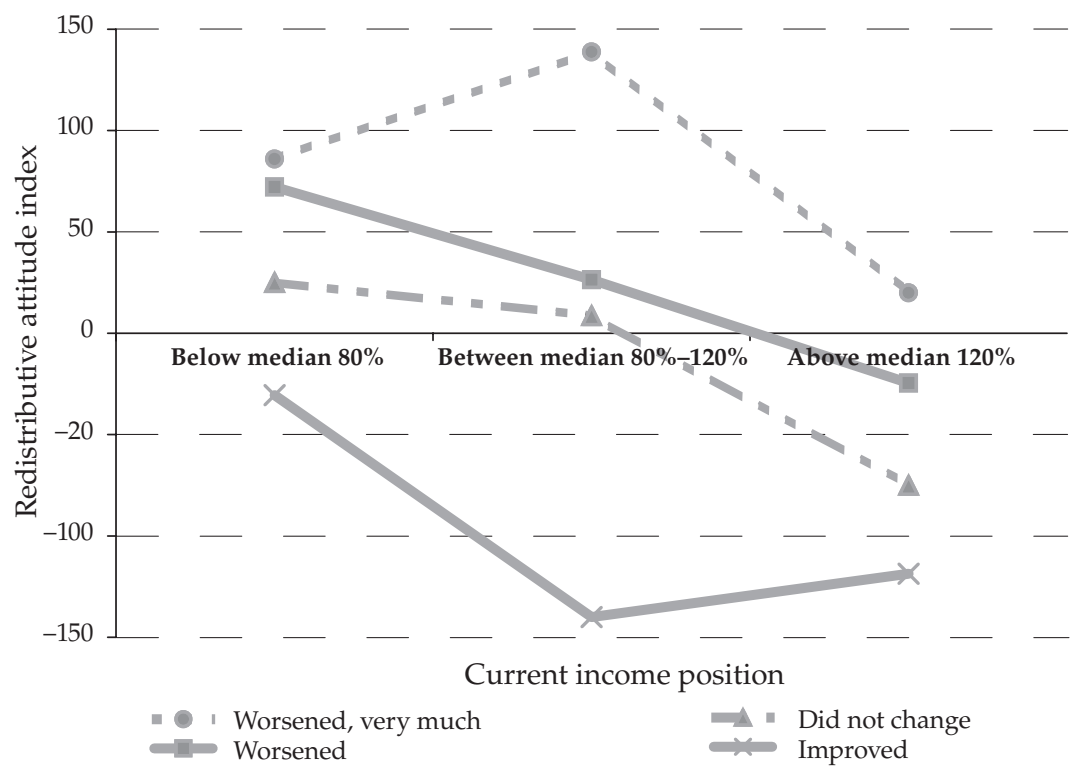

Panel B: Values of the redistributive index by income mobility expectations for the next year

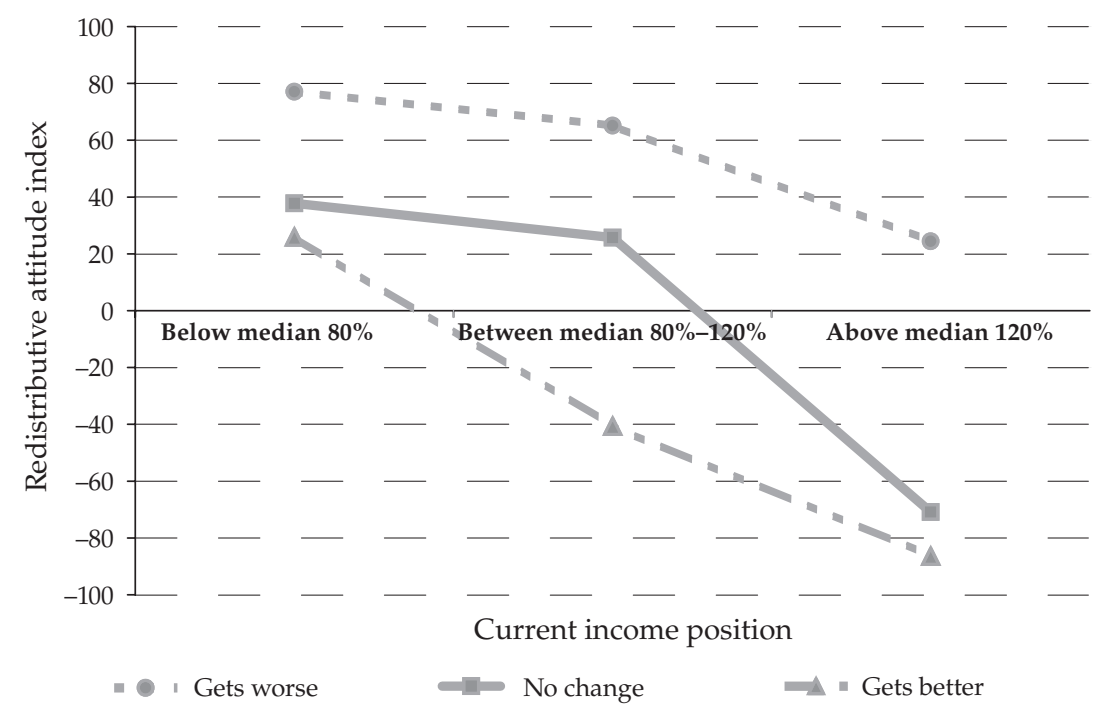


rienced upward mobility). Confidence that income prospects will improve in the future also corresponds with a lower demand for redistribution: at higher income levels, this relationship is stronger. To be fair, although those with below median and above-median incomes do exhibit differences in their redistributive attitudes depending on their perceived mobility prospects, the lower income segments always remain on the positive side and the above-median segments always remain on the negative side of the redistribution index scales. Still, there are some exceptions: even those people who are well below the median-income level may on average opt for less redistribution if they rank among the upwardly mobile (that is, among those who report a significant improvement in their families' material position in the past). Similarly, even those people who belong to an income category that has much higher income than the median may support some redistribution if they feel that they lost ground in the past or fear losing ground in the future.

Also important is the evaluation of subjective mobility, which seems to matter more for middle-income categories than for the better off or the less well off. This differentiating impact is especially strong in the case of past subjective mobility (although it appears also to be present in the case of expectations).

To put it differently: a decline or an improvement in perceived social mobility seems to lead to larger swings in demand for redistribution among the middle classes than among the poor or among the rich.

In terms of general welfare attitudes (measured by the ideological question about an individual's responsibility over his or her own fate versus the duty of the state to provide for various contingencies), the inclination to support state involvement seems to correlate with a higher level of demand for redistribution, while disagreement with the 'inequalities are too large' statement seems to correspond to a lower level of support for the involvement of state solutions in the measured fields that are the focus of this analysis (Table 3). Finally, risk-takers have much less of a taste for redistribution than risk-averse people do.

\section{Multivariate results}

Simple OLS regressions were used to predict the demand for redistribution in a multivariate context (Table 4). The first model shows a baseline containing basic socio-demographic variables (age, gender, education and place of residence). These variables are controlled for each consecutive model. Model 2 contains, in addition, two predictors representing immediate material self-interest: personal equivalent household incomes on the one hand, and the labour market activity of respondents on the other (both converted into dummies leaving middle incomes and employee status as references categories). In the third model a series of dummies representing subjective past mobility experience and future expectations are introduced. The latter variable is the typical proxy of the POUM phenomenon, but given that future expectations are largely embedded in past experiences, the 
Table 3. The average value of the redistributive attitude index by the level of inequality tolerance and by general ideological attitude*

\begin{tabular}{|c|c|c|c|c|}
\hline \multicolumn{4}{|c|}{ Degree of agreement: 'inequalities are too large in this country' } & $(\mathrm{F}: 23,4)$ \\
\hline Full agreement & Rather agrees & Neither-nor & \multicolumn{2}{|c|}{ Disagrees } \\
\hline 25 & -47 & -99 & \multicolumn{2}{|c|}{-45} \\
\hline \multicolumn{4}{|c|}{ Preferences regarding individual versus collective responsibility for one's own fate } & $(\mathrm{F}: 43,8)$ \\
\hline $\begin{array}{l}\text { Individual } \\
\text { responsibility }\end{array}$ & 2 & 3 & \multicolumn{2}{|c|}{$\begin{array}{c}\text { State } \\
\text { responsibility }\end{array}$} \\
\hline-20 & -58 & 10 & \multicolumn{2}{|c|}{105} \\
\hline \multicolumn{4}{|l|}{ Risk attitude } & $(\mathrm{F}: 40,5)$ \\
\hline \multicolumn{2}{|c|}{ Risk-averse } & \multicolumn{3}{|c|}{ Risk-taker } \\
\hline \multicolumn{2}{|c|}{10} & \multicolumn{3}{|c|}{-97} \\
\hline
\end{tabular}

*F statistics in brackets

first variable of past mobility experience is also grouped here. This set of variables is called the model for 'extended self-interest', as in addition to the immediate material circumstances, evaluations and expectations are also included. The fourth model introduces the variables about individualistic traits (risk aversion and individualistic attitude), while the fifth model introduces inequality aversion to show the separate effects of inequality tolerance on the demand for redistribution. Finally, the sixth is a full model containing all the variables.

The OLS results show gradual improvements in the consecutive models, though the models in general do not perform very well (the adjusted $\mathrm{R}$ squares of the magnitude between $6 \%$ and $10 \%$ are all very low). The coefficients have the expected signs in each case but the magnitude and significance of the relationships require comments.

From the observation of the control variables in the base model, several important conclusions emerge. First and foremost, it is quite striking how important the role of education is in determining redistributive preferences. All coefficients are high and significant at a level of $1 \%$. Since the reference category here is the group who have only primary or a lower level of education, it is safe to conclude that people with the lowest education are significantly more in favour of redistribution than the other education categories. Also, it is important to note that the effect of place of residence remains strong in each of the models, suggesting that attitudes in the capital of the country are significantly different from those in the countryside, and these differences cannot be attributed just to composition effects (that is, to the large share of people who have a higher level of education in Budapest). Third, despite the fact that the dummies for age were constructed in considerable detail (to tackle potential non-linearities, with the 50-59 age group 


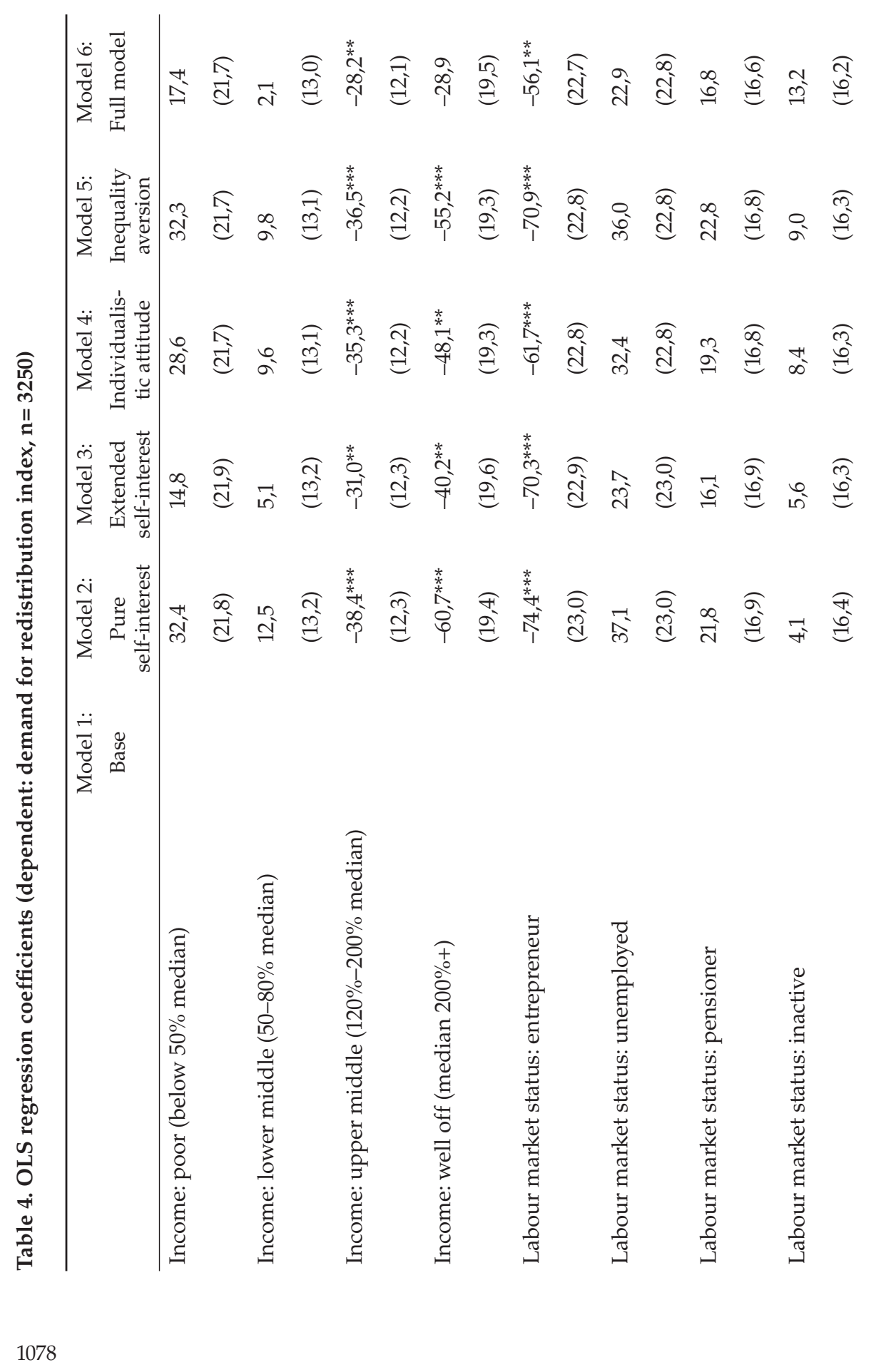




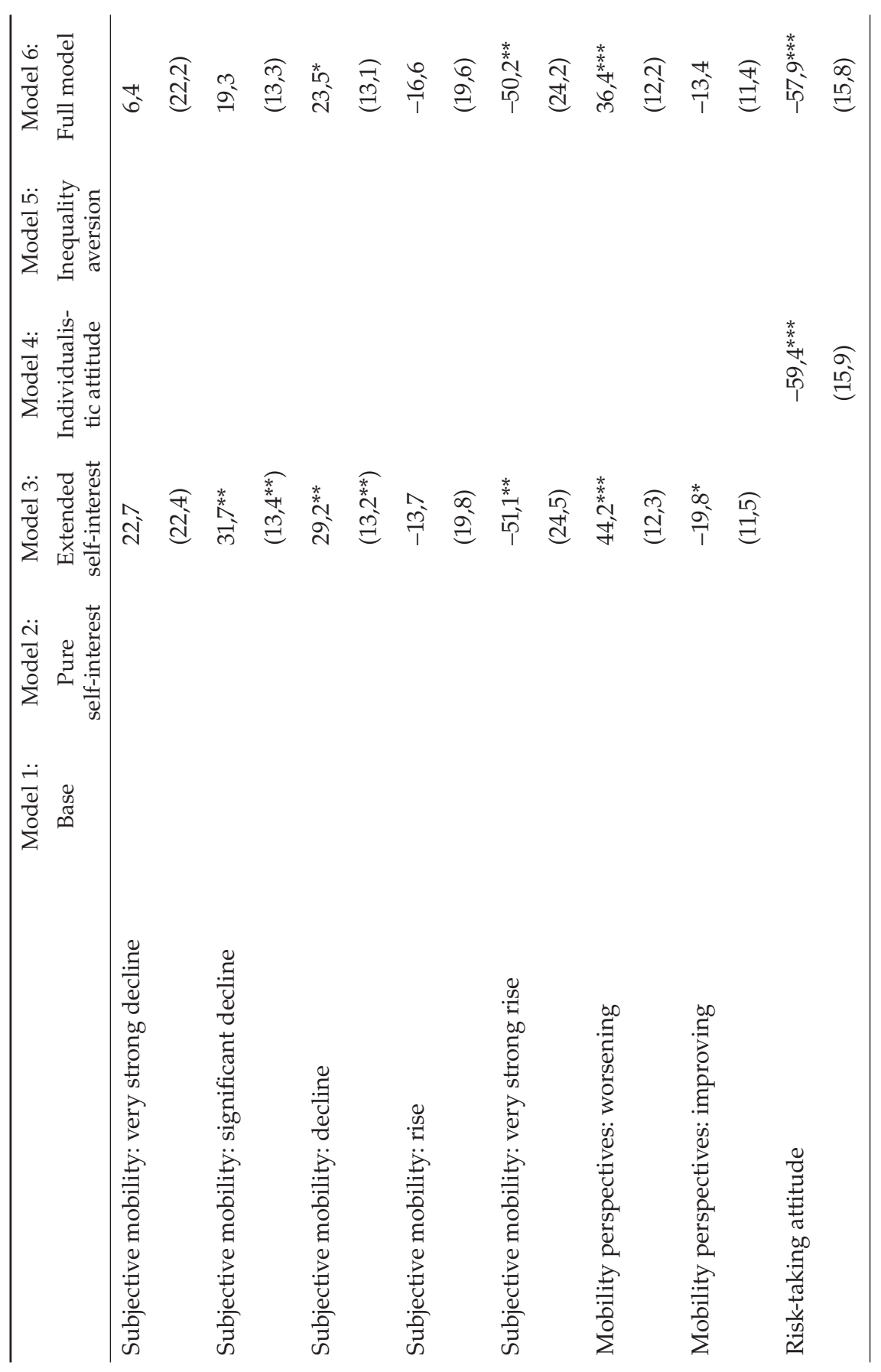




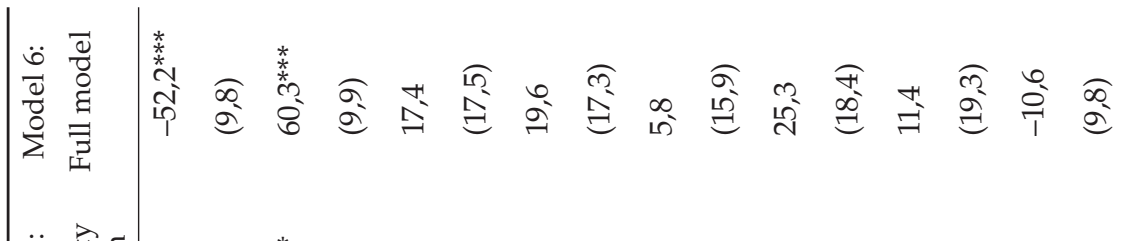

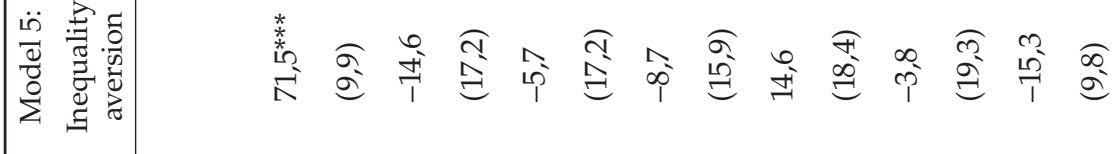

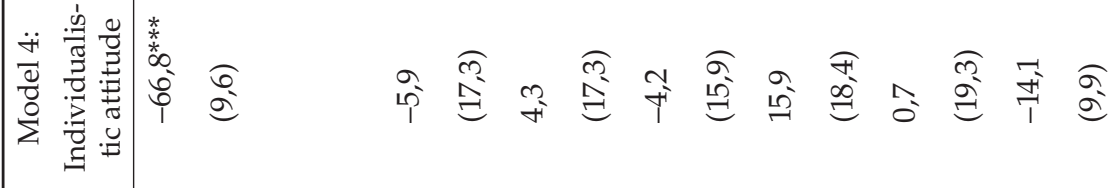

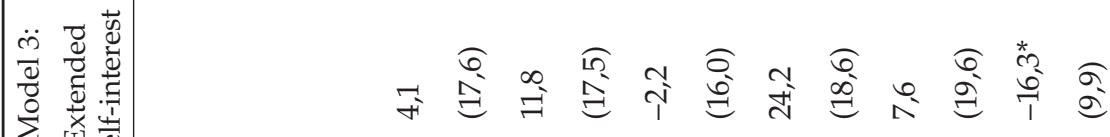

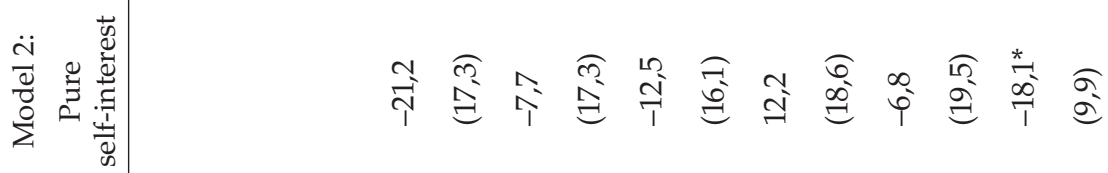

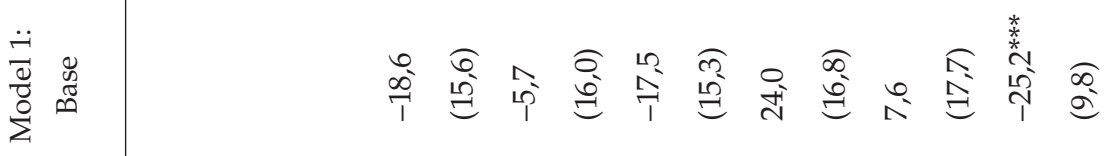

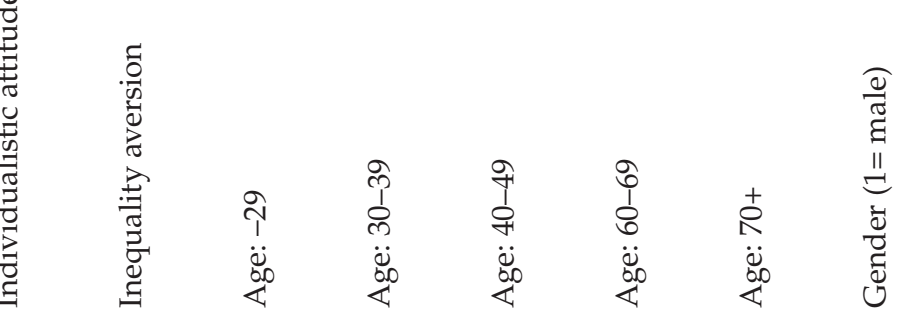




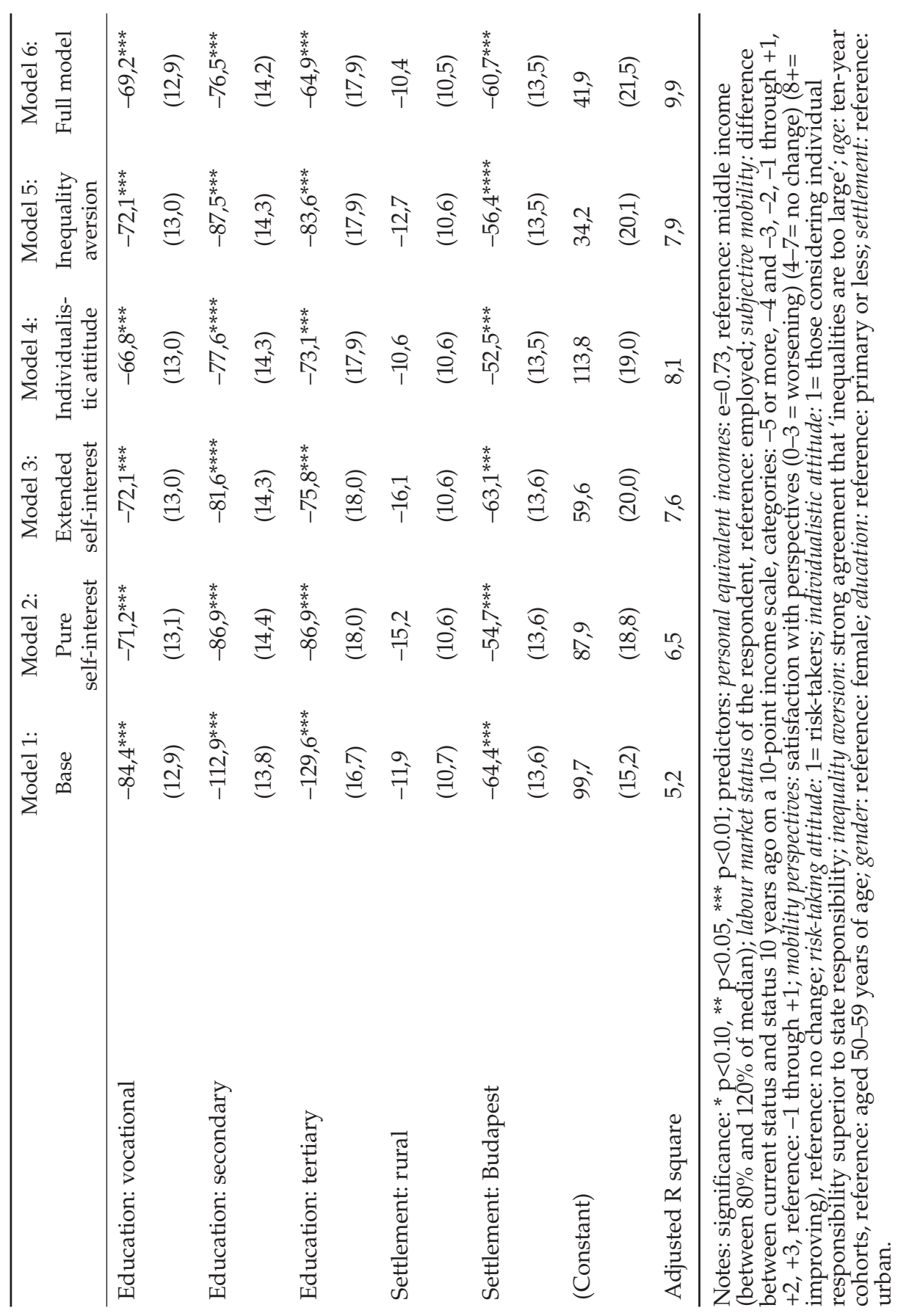


designated as the reference category), no significant relationship was found. Gender differences in the base model are significant (men showing less taste for redistribution than women). However, these differences seem to evaporate in the consecutive models. These last two points support the conclusion that reliance on state redistribution relates more to socio-economic variables than to demographic ones.

The introduction of the pure self-interest variables resulted in a weakening of the estimates for education, gender and place of residence, both in terms of significance and in terms of the magnitude of the parameter estimates (Model 2). The role of income appears to be important, though it seems that it is not low income that explains higher redistributive claims but the other way round: pro-market views seem to be concentrated mostly in the higher income groups. Similar can be said about the labour market status of the respondents. When contrasted with the attitudes of the employed, pensioners and people who are economically inactive do not differ that much. Instead, the group of self-employed and entrepreneurs shows significantly less support for redistribution and state involvement in general than the reference group of employees.

The introduction of past mobility experience and future expectations as predictors brings in some significant factors. The introduction of these two variables 'takes away' some of the explanatory power of current incomes (though incomes retain their significance at a $5 \%$ level in this model, too). Past mobility experience appears to be inversely related to redistributive preferences, though somewhat asymmetrically: while even the experience of a slight decline is associated with a significantly stronger demand for redistribution, it is only a very strong increase (of at least three points on a scale of ten) that corresponds to a significantly lower level of redistributive tastes. The introduction of future mobility prospects does show a positive and significant effect on the demand for redistribution, all other things remaining constant. To sum up, the signs of the two subjective mobility variables are in line with our expectations: the better the past mobility experience was and the better the future prospects are, the less inclined a respondent will be to choose the statist option, further confirming the POUM hypothesis of Bénabou and Ok [2001]. ${ }^{13}$

In Model 4, both variables are significant and negative for individualistic socio-economic attitudes. The coefficients and signs of a risk-taking attitude and of the position on an individualism/paternalism scale support the interpretation that the more a respondent agrees that individuals (rather than the state) should have to bear responsibility for their lives, the lower their redistribution index will be. People with a risk-taking attitude in job-market decisions agree to statist op-

13 These findings are widely consistent with the findings of Molnár and Kapitány [2006, 2007], who, based on a household budget survey, present a different analysis of the demand for redistribution on Hungarian data. They find that redistributive preferences depend on both objective and subjective conditions. Also, their findings support the POUM hypothesis and lead to the conclusion that inequality tolerance may be a major factor. 
tions to a lesser extent. This effect seems to be fairly strong. It should be noted that adding these variables into the pure self-interest model increases the explained variance of the models more than the introduction of subjective the base variables did. Finally, inequality aversion, when introduced, shows a significant value and a positive sign, meaning that, all other things remaining constant, being dissatisfied with the perceived level of income inequalities leads to a greater demand for redistribution.

\section{Conclusion}

In this article, an attempt was made to explain attitudes towards redistribution in the Hungarian context. To perform this, data from the 2003 wave of the Tárki Household Monitor dataset was used. Several alternative explanations of redistributive attitudes were tested in the article. In addition to conventional class differentials, the article revealed differences by various subjective evaluations of inequalities, differences in the level and change of estimates of relative personal positions, and differences by general individualistic attitudes. Rather than identifying pro-state groups, the generally high level of popular support for state redistribution makes it easier to identify those who were less in favour of state redistribution: the entrepreneurs, the upper middle income strata and some subgroups of the higher educated are important representatives of this attitude.

The article showed that demand for redistribution correlates negatively with actual (and perceived) incomes and with past mobility experiences. Expectations for the future mobility of the respondents, although they are not overriding, add to the explanatory power of the models. People expecting improvements in their income situations are less in favour of the statist options, while those facing uncertainties in their personal future show more taste for redistribution. The findings of this article call for a broader understanding of self-interest and warn that it is necessary to detach it from actual, objective income levels and material positions. Perceptions of (levels of and changes to) actual incomes and confidence in the future development trajectories of respondents' households play an important role. In other words, the belief that things will get better in the future decreases the redistributive expectations of even those who may be currently in need of help. This supports Bénabou's and Ok's POUM hypothesis [2001], which is another achievement of this article.

Although, generally, paternalistic attitudes are important, the effect of the (in)tolerance for inequalities in defining the demand for redistribution is also very significant. Therefore, it may well be that the lower tolerance for inequalities defines both the larger demand for redistribution and (to some extent) widespread paternalistic attitudes, at least in the context of the transition from socialism to capitalism. The findings of this article fully support other recent findings on Hungarian attitudes. 
The article also reached other conclusions. The first is related to the fact that we measured attitudes towards a broader range of state activities. This differs from most of the studies in the literature that measure the demand for redistribution with a single question about the need to redistribute to reduce the degree of inequalities. The measure used in this article includes items such as the labour market, housing, education, health and social policy interventions, and protectionist agricultural policies. This helps produce a clearer understanding of the political economy of budget formation and electoral cycles than analyses based only on single questions about a call for a reduction of (vertical) income inequalities.

One very important finding in this article is that education matters a great deal in explaining welfare attitudes. However, I would not conclude that the change in the shape of preferences (were this a policy target) could easily be achieved by educative campaigns. The fact that respondents' answers correspond to their school attainment is most likely related to cultural differences within the electorate and to the fact that education is strongly correlated with economic affluence. To put it differently, the lack of education may correspond to poverty and bad economic circumstances, which paves the way to more intensive pro-state attitudes.

An important future research direction could be to relate actual government spending levels to the spread of welfare attitudes and to the level of income (in)tolerance and to analyse actual levels of inequalities. This could help in determining how redistributive demand, inequality aversion and actual inequality levels interrelate (especially in the context of post transition countries).

Finally, another important finding of the article is that middle-income groups seem to be more sensitive to perceived shifts in material position than better-off or worse-off groups. This also has a policy consequence: welfare reforms aimed at decreasing the excess burden on the state should start by bargaining with the middle classes. ${ }^{14}$

The ultimate test of attitudes is elections, which occur at periodic intervals. Clearly, voting rights can only be exercised in person, and at election time it is the act of voting that makes preferences visible. Therefore, turnout on elections becomes an important issue and differences in the political participation of the

\footnotetext{
14 The traditional left-right dimension does not seem to have been working in the past five years in Hungary. For example, Fábián and Tóth [2008] found that while in 2003 the prostate and pro-market attitudes did somewhat correspond to ideological self-identification along these traditional lines, nowadays there has been a shift away from this pattern. Party preference came to be significant in explaining redistributive attitudes, but in an unusual way: leftist voters seem to support reformist, liberal measures, while the rightist part of the electorate is significantly more statist in its attitudes. The causes behind this change are certainly open to debate, because the question has yet to be answered as to whether people urge parties to redistribute more or parties try to gain votes by offering various promises of a free lunch.
} 
affluent and of the poorer segments of society [Bénabou 2000; Larcinese 2007] may lead to less (or more) redistribution than would be predicted from the MR model. After all, turnout plays a major role in defining electoral outcome and, via that, public spending priorities. But this could be the topic of the next study on redistributive preferences.

IstVÁN GYÖRGY TótH is director of the Budapest-based Tárki Social Research Institute Inc., an independent research company specialising in applied social science analyses and polling (http://www.tarki.hu/en/). He has a PhD in sociology and has a privatdozent from Budapest Corvinus University. He has directed several research projects, including the Hungarian Household Panel Study and a number of other projects on income distribution and social policies. He is co-editor of the bi-annual 'Hungarian Social Report' series since 1998.

\section{References}

Alesina, A., R. Di Tella and R. MacCulloch. 2004. 'Inequality and Happiness: Are Europeans and Americans Different?' Journal of Public Economics 88 (9-10): 2009-2042.

Alesina, A. and E. L. Glaeser. 2006. Fighting Poverty in the US and Europe: A World of Difference. Oxford: Oxford University Press.

Alesina, A. and E. La Ferrara. 2005. 'Preferences for Redistribution in the Land of Opportunities.' Journal of Public Economics 89 (5-6): 897-931.

Alesina, A. and N. Fuchs-Schündeln. 2005. 'Good Bye Lenin (or Not?): The Effect of Communism on People's Preferences.' Working Paper 11700. National Bureau of Economic Research, Cambridge.

Bénabou, R. 1996. 'Inequality and Growth.' Pp. 11-74 in NBER Macroeconomics Annual, edited by B. S. Bernanke and J. J. Rotemberg. Cambridge, MA: MIT Press.

Bénabou, R. 2000. 'Unequal Societies: Income Distribution and the Social Contract.' American Economic Review 90 (1): 96-129.

Bénabou, R. and E. A. Ok. 2001. 'Social Mobility and the Demand for Redistribution: The Poum Hypothesis.' Quarterly Journal of Economics 116 (2): 447-487.

Borck, R. 2007. 'Voting, Inequality and Redistribution.' Journal of Economic Surveys 21 (1): 90-109.

Bratsberg, B., K. Røed, O. Raaum, R. Naylor, M. Jäntti, T. Eriksson, E. Österbacka and A. Björklund. 2006. 'American Exceptionalism in a New Light: A Comparison of Intergenerational Earnings Mobility in the Nordic Countries, the United Kingdom and the United States.' Discussion Paper No. 1938. IZA, Germany.

Corneo, G. and H. Grüner. 2002. 'Individual Preferences for Political Redistribution.' Journal of Public Economics 83: 83-107.

Fábián, Z. and I. G. Tóth. 2008. 'Pártpreferencia csoportok politikai azonosulása és redisztribúciós attitúdjei.' (Political Identity and Redistribution Attitudes of Party Preference) Pp. 387-414 in Társadalmi riport 2008, edited by T. Kolosi and I. Tóth. Budapest: Tárki.

Fong, C. 2001. 'Social Preferences, Self-interest, and the Demand for Redistribution.' Journal of Public Economics 82 (2): 225-246. 
Gijsberts, M. 2002. 'The Legitimation of Income Inequality in State-socialist and Market Societies.' Acta Sociologica 45: 269-285.

Glaeser, E. L. 2005. 'Inequality.' NBER Working Paper No. W11t11. (www.nber.org/papers/w11511).

Hirschman, A. O. 1973. 'Changing Tolerance for Income Inequality in the Course of Economic Development.' Quarterly Journal of Economics 87: 544-566.

Kelley, J. and K. Zagorski. 2004. 'Economic Change and the Legitimation of Inequality: The Transition from Socialism to the Free Market in Central-East Europe.' Pp. 319-364 in The Shape of Social Inequality: Stratification and Ethnicity in Comparative Perspective. (Research in Social Stratification and Mobility, Vol 22), edited by D. B. Bills. Amsterdam: Elsevier.

Kolosi, T. and I. G. Tóth. 2008. Társadalmi riport 2008. Budapest: Tárki.

Larcinese, Valentino. 2007. 'Voting over Redistribution and the Size of the Welfare State: The Role of Turnout.' Political Studies 55: 568-585.

Lübker, M. 2007. 'Inequality and the Demand for Redistribution: Are the Assumptions of the New Growth Theory Valid?' Socio-Economic Review 5 (1): 117-148.

Meltzer, A. H. and S. F. Richard. 1981. 'A Rational Theory of the Size of Government.' The Journal of Political Economy (89) 5: 914-927.

Milanovic, B. 2000. 'The Median Voter Hypothesis, Income Inequality and Income Redistribution: An Empirical Test with the Required Data.' European Journal of Political Economy 16: 367-410.

Moene, K. O. and M. Wallerstein. 2001. 'Inequality, Social Insurance, and Redistribution.' The American Political Science Review 95 (4): 859-874.

Molnár, G. and Z. Kapitány. 2006: Mobility, Uncertainty and Subjective Well-being in Hungary. Discussion Paper MT-DP 2006-5. Institute of Economics, Hungarian Academy of Sciences.

Molnár, G. and Z. Kapitány. 2007. 'Bizonytalanság és a jövedelmek újraelosztása iránti igény Magyarországon.' (Uncertainty and the Demand for Redistribution in Hungary) Közgazdasági Szemle. LIV: 201-232.

Murthi M. and E. R. Tiongson. 2008. 'Attitudes to Equality: The "Socialist Legacy" Revisited.' The World Bank Policy Research Working Paper 4529, February 2008.

OECD. 2008. Growing Unequal? Income Distribution and Poverty in OECD Countries. Paris: OECD.

Osberg, L. and T. Smeeding. 2006. "“Fair” Inequality? Attitudes toward Pay Differentials: The United States in Comparative Perspective.' American Sociological Review 71: 450-473.

Palócz, É. 2008. 'Makrogazdasági folyamatok és fiskális politika Magyarországon nemzetközi összehasonlításban.' (Macro-economic Processes and Fiscal Policy in Hungary in International Comparison) Pp. 189-203 in Társadalmi riport 2008, edited by T. Kolosi and I. G. Toth. Budapest: Tárki.

Picketty, T. 1995. 'Social Mobility and Redistributive Politics.' The Quarterly Journal of Economics 110: 551-584.

Ravallion, M. and M. Loskhin. 2000. 'Who Wants to Redistribute? The Tunnel Effect in 1990s Russia.' Journal of Public Economics 76: 87-104.

Rawls, J. 1971. A Theory of Justice. Cambridge, Mass.: Harvard University Press.

Senik, C. 2005. Income Distribution and Well-being: What Can We Learn from Subjective Data? Journal of Economic Surveys 19 (1): 43-63.

Senik, C. 2006: 'Ambition and Jealousy: Income Interactions in the "Old" Europe versus the "New" Europe and the United States.' IZA Discussion Papers No. 2083. Institute for the Study of Labour (IZA) Germany. 
Suhrcke, M. 2001. 'Preferences for Inequality. East vs. West.' Innocenti Working Paper No. 89. Florcence: UNICEF Innocenti Research Centre.

Svallfors, Stefan. 1997. 'Worlds of Welfare and Attitudes to Redistribution: A Comparison of Eight Western Nations.' European Sociological Review 13 (3): 283-304.

Szivós, P. and I. G. Tóth (eds.). 2008. 'Köz, teher, elosztás.' Tárki Monitor Jelentések 2008. Tárki Monitor Research Support Series.

Tóth, I. G. 2005. Jövedelemeloszlás. A gazdasági rendszerváltástól az uniós csatlakozásig. (Income Distribution. From the Systemic Change to the Joining of the European Union) Budapest: Andorka Rudolf Társadalomtudományi Társaság-Századvég Kiadó.

Tóth, I. G. (ed.) 2008. Tárki European Social Report. Budapest: Tárki.

Tóth, I. G. 2006. 'Measured and Perceived Income Distribution: Tunnel Effect, Reference Group Shifts and Skill Biased Transition in Hungary, 1987-2005.' Paper presented at the 29th IARIW General Conference, Joensuu, Finland 20-26 August, 2006.

Vanhuysse, P. 2006. Divide and Pacify. Strategic Social Policies and Political Protests in Post-Communist Democracies. Budapest: Central European University Press

Wong, Wei-Kang. 2004. 'Preferences for More Income Equality: Deviations from Pocketbook Voting and Implications for the Median Voter Theorem.' Dept of Economics, National University of Singapore, mimeo.

(http://nt2.fas.nus.edu.sg/ecs/res/seminar-papers/09112004.pdf) 


\title{
Finance a úvěr
}

\author{
Czech Journal \\ of Economics and Finance
}

A refereed academic journal published by the Faculty of Social Sciences,

Charles University, Prague, in cooperation with the Czech National Bank and the Czech Ministry of Finance.

The journal's 2007 impact factor is the highest of all economics/finance journals in the region and similar to distinguished international journals, such as the Journal of Macroeconomics and Journal of Policy Modeling. The journal is indexed in all the major databases, such as JEL-ECONLIT, SCOPUS, SSCI, Ulrich's International Periodicals Directory, and ABI-INFORM.

FaÚ-CJEF publishes articles exclusively in English. The articles appear simultaneously in the printed version and on the web. The web version is accessible free of charge.

The journal pays special attention to monetary economics, public finance, and financial economics, but is open to high quality papers from all fields. Preference is given to empirically oriented papers that are relevant to international audience.

Continuing a tradition of single-topic issues, the latest issue of the journal (9-10/08) contains a symposium on:

\section{YEARS OF CZECH INFLATION TARGETING}

Kateřina Šmídková, Aleš Bulír, and Martin Čihák: ‘Hits and Misses: Ten Years of Czech Inflation Targeting' (Introduction)

Juraj Antal, Michal Hlaváček, and Tomáš Holub: 'Inflation Target Fulfillment in the Czech Republic in 1998-2007: Some Stylized Facts'

Tomáš Holub: 'Causes of Deviations from the CNB's Inflation Targets: An Empirical Analysis'

Juraj Antal, Michal Hlaváček, and Roman Horváth: 'Do Central Bank Forecast Errors Contribute to Missing of Inflation Targets? The Case of the Czech Republic'

Jaromír Hurník, Ondřej Kameník, and Jan Vlček: 'The History of Inflation Targeting in the Czech Republic Through the Lens of a Dynamic General Equilibrium Model' Roman Horváth: 'Asymmetric Monetary Policy in the Czech Republic?'

Roman Horváth: 'Undershooting of the Inflation Target in the Czech Republic:

The Role of Inflation Expectations'

http://journal.fsv.cuni.cz 